\title{
STRATEGIC DIAGNOSIS OF LIVESTOCK-FOREST INTEGRATION SYSTEMS IN NORTHERN MATO GROSSO
}

\author{
Roni Djeison Ansolin ${ }^{1 *}$, Romano Timofeiczyk Junior ${ }^{2}$, João Carlos Garzel Leodoro da Silva ${ }^{2}$, Miquéias \\ Michetti ${ }^{3}$, Mariana Yumi Takahashi Kamoi ${ }^{4}$, Julio Cesar dos Reis ${ }^{5}$

\begin{abstract}
${ }^{1 *}$ Federal University of Paraná, Graduate Program in Forest Engineering, Curitiba, Paraná, Brazil - roni_ansolin@ hotmail.com ${ }^{2}$ University of Paraná, Department of Rural Economy and Extension, Curitiba, Paraná, Brazil - romano.timo@ @mail.com; garzel@ufpr.br ${ }^{3}$ Instituto Mato-Grossense de Economia Agropecuária, Mato Grosso, Paraná, Brazil - miqueias@imea.com.br ${ }^{4}$ Fundação Eliseu Alves, Rede TT ILPF, Cuiabá, Mato Grosso, Brazil - mariana.ytakahashi@gmail.com ${ }^{5}$ Embrapa Agrossivipastoril, Sinop, Mato Grosso, Brazil - julio.reis@embrapa.br
\end{abstract}

Received for publication: 15/07/2018 - Accepted for publication: 27/05/2019

\begin{abstract}
Resumo
Diagnóstico estratégico para sistema de integração pecuária-floresta, inseridos na região norte do estado de Mato Grosso. O presente trabalho teve por objetivo elaborar um diagnóstico estratégico sobre a inclusão do componente florestal (teca) em áreas de pecuária extensiva, no município de Alta Floresta, estado de Mato Grosso. Para isso, foi elaborada a análise SWOT adaptada, inicialmente foram identificados os pontos fortes e fracos para o ambiente interno (entrevistas), bem como as oportunidades e ameaças para o ambiente externo (consulta bibliográfica); e por fim, foi elaborada a matriz de fatores internos e externos. Os dados para a elaboração do diagnóstico foram obtidos por meio de entrevistas semi estruturadas com alguns agentes-chave da cadeia agroindustrial, composta por (3) produtores, (3) gerentes de fazenda, (2) profissionais técnicos do setor produtivo da pecuária e florestal e (3) colaboradores de instituições públicas e por meio de consulta bibliográfica. As respostas foram pontuadas por caráter de relevância, conforme o posicionamento dos entrevistados. A pontuação total ponderada dos fatores internos e externos foi de 2,83 e de 3,24, respectivamente, maior que a média 2,5, indicando que o sistema de integração é internamente forte e a região está sob um ambiente externo favorável. O diagnóstico produzido indica que a integração pecuária-floresta é uma atividade atrativa, promovendo a diversidade da produção e colaborando com o desenvolvimento local. Contudo, deve haver planejamento estratégico por meio de ações eficientes, entre diferentes partes interessadas (governo, setor público e privado) a fim de fomentar esta atividade, bem como garantir condições para a consolidação do sistema de integração pecuária-floresta, visto o seu grande potencial frente aos sistemas de monocultura.
\end{abstract}

Palavras-chave: Desenvolvimento rural; teca; pecuária extensiva; planejamento regional.

\begin{abstract}
The objective of this study was to elaborate a strategic diagnosis about integrating the forest component (teak) into extensive cattle raising areas, in Alta Floresta, northern Mato Grosso state. For this, the SWOT analysis consisted of initially identifying the internal factors, the strengths and weaknesses internal to the organization (interviews) and the external factors, opportunities and threats external to the organization (bibliographic search) to elaborate the External and Internal Factor Evaluation Matrices. The data were obtained from applying semi-structured interviews to some of the key players in the agro-industrial chain, such as (3) producers, (3) farm managers, (2) professional technicians from the livestock field, and (3) collaborators of public institutions, and a bibliographic search/review as well. The answers given by each interviewee were scored according to their relevance. The scores assigned to internal and external factor evaluations were 2.83 and 3.24, higher than the average 2.5 , indicating that the integration of forest with pasture areas is internally strong while the studied region has a favorable external environment. In general, the produced diagnosis indicates that the integration of livestock-forest is an attractive activity, promoting production diversity and collaborating with local development. However, there must be strategic planning between the different key players (government, public and private sectors) in order to foster the most appropriate activities for the region, guaranteeing the conditions for the consolidation of the forest-livestock integration system, given its great potential in relation to monoculture systems.

Keywords: Rural development; teak; extensive livestock; regional planning.
\end{abstract}

\section{INTRODUCTION}

The integration between forest species and the agricultural or/and livestock component may be an interesting alternative to traditional monoculture systems since it can diversify production, reduce risks, benefit 
animal welfare and result in potential carcass gain (TURINI et al., 2015), in addition to the environmental benefits generated by forests.

To this end, the Crop-Livestock-Forest Integration (CLFI) concept consists of a sustainable production system that integrates agricultural, livestock and forest activities in the same area, to promote high yields and dilute costs due to synergy between the components (BALBINO et al., 2011; VILELA et al., 2011; CORDEIRO et al., 2015). These authors also state that such systems are configured as an alternative to monoculture and extensive activities while meeting the needs for ecological and economic improvements such as soil conservation and increasing income, especially in regions where livestock and the use of natural resources are already intensified.

Alta Floresta, the studied municipality, is a prominent beef producer and a highly important producer of the forest species Tectonia grandis L. f., in addition to having large areas and good edaphoclimatic conditions for agricultural activities (IBGE, 2016). Further, the municipality and the state are focused on implementing various private and political initiatives, given the environmental implications arising from the current land use in the region (VIEIRA FILHO and GASQUES, 2016).

However, although proven to be advantageous (OLIVEIRA JÚNIOR et al., 2016; CORDEIRO et al., 2015) and with expanding potential in the state of Mato Grosso, integration systems still cause skepticism and uncertainty among producers and investors, especially to the market, when the proposed system involves activities outside their domain. This was true for the cattle beef farmers of Alta Floresta in Mato Grosso, whose predominant activity is extensive cattle raising while the forest activity is still not widespread (BAMBOLIM and DONDE, 2017).

Therefore, Pires et al. (2016) concluded that a diagnosis analysis becomes necessary, the objective is to define strategies seeking to determine the positive and negative points of the business initiative, as well as the opportunities and threats, which are fundamental steps for formulating/proposing a business strategy. Therefore, the SWOT analysis (strengths, weaknesses, opportunities and threats analysis) allows elaborating such a diagnosis, besides being a complementary tool that can help producers, public managers and other key players of the forest productive chain in the decision-making process.

The SWOT analysis is a widely used tool in business strategy formulation. Marques et al. (2015) and Biassio and Silva (2015) indicate that this method of analysis is simple and centered on identifying and grouping information into two main categories, the internal factors, strengths and weaknesses, and the external factors, the opportunities and threats of the diagnostic object.

Given the above and to understand better the producer doubts and uncertainties about including a new forest activity, such as teak production to their extensive livestock activity, the present study aimed at evaluating the perception of some key players in the agricultural sector of Alta Floresta, Mato Grosso, about integrating the forest component, the species Tectona grandis L. f. (teak), into extensive livestock areas, using the adapted SWOT analysis method.

\section{MATERIAL AND METHODS}

\section{Study site}

This study was conducted in Alta Floresta, in northern Mato Grosso. The regional relief is disadvantageous for planting crops, so livestock became the main economic activity in the area. But as the agroindustrial sector grows, several industries are being implanted in the region, particularly, preserves, coffee and rice processing in the agriculture sector; dairy and slaughterhouses in the livestock sector; as well as furniture, timber, and guarana (non-timber) in the forestry sector (IBGE, 2016 and 2010).

The region climate is Aw, tropical with a dry season, according to Köppen-Geiger classification, with approximately $24^{\circ} \mathrm{C}$ annual average temperature and $270 \mathrm{~m}$ altitude. There are two well-defined seasons, with four months of drought, from May to August, and low relative humidity (lower than $12 \%$ sometimes) in August and September. The annual precipitation is $1,750 \mathrm{~mm}$, with maximum intensity in December, January, and February.

Data were collected from three rural properties that practice the Livestock-Forest Integration System (LFIS) in this study area (Figure 1). The evaluated farms integrated the forest component (teak) into the pasture areas that had already shown signs of degradation, thus requiring soil preparation and management before forest planting. The livestock component is usually introduced from the third year, after the tree trunks are formed, to avoid damage to the trees, remaining until the end of the cycle, depending on the final product (calf, lean ox or slaughter).

FLORESTA, Curitiba, PR, v. 50, n. 1, p. 1001 - 1010, jan/mar 2020 Ansolin, R. D. et.al 


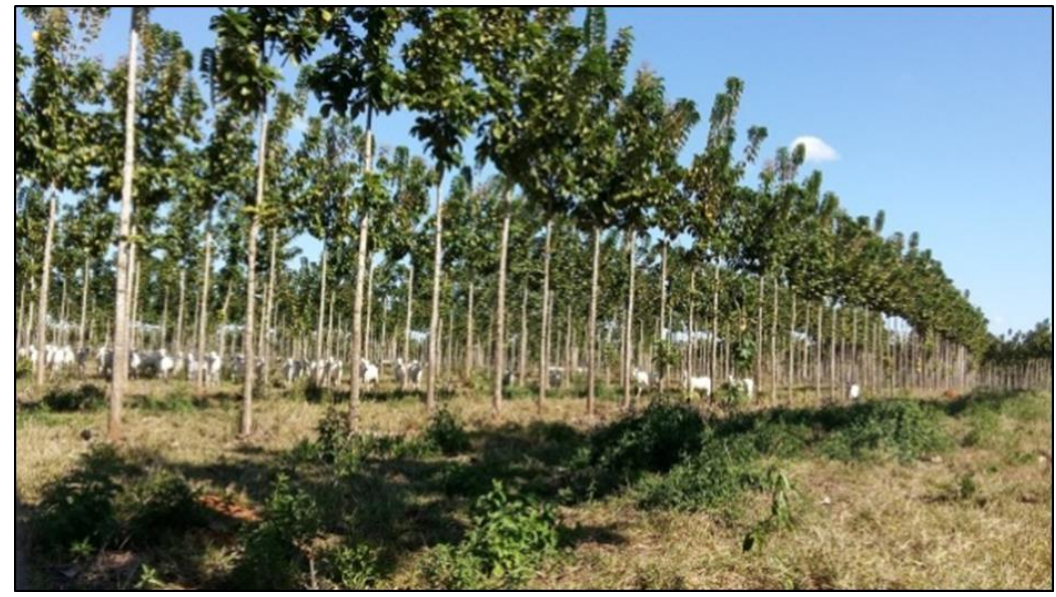

Figura 1. Sistema de integração Pecuária-Floresta, gado nelore e espécie teca, em uma das fazendas avaliadas. Figure 1. Livestock-Forest integration system, Nellore cattle herd and teak species, in one of the assessed farms. SOURCE: The authors (2018).

In addition, the integration between livestock and forest creates a very complex production system, raising issues such as competition between teak and other surrounding plants, and the fact that falling leaves may hinder the growth of undergrowth/low-growing plants (DAMASIO et al., 2015). To alleviate such issues, each area should be analyzed to plan the best spacing arrangement between components and choose appropriate forages.

\section{Analysis of Strategic Diagnosis}

The analysis of the strategic diagnosis used the adapted SWOT method. Initially, the internal and external factors were characterized and delimited (Figure 2), to identify the strengths and weaknesses, and opportunities and threats, respectively, associated with the livestock-forest integration activity.

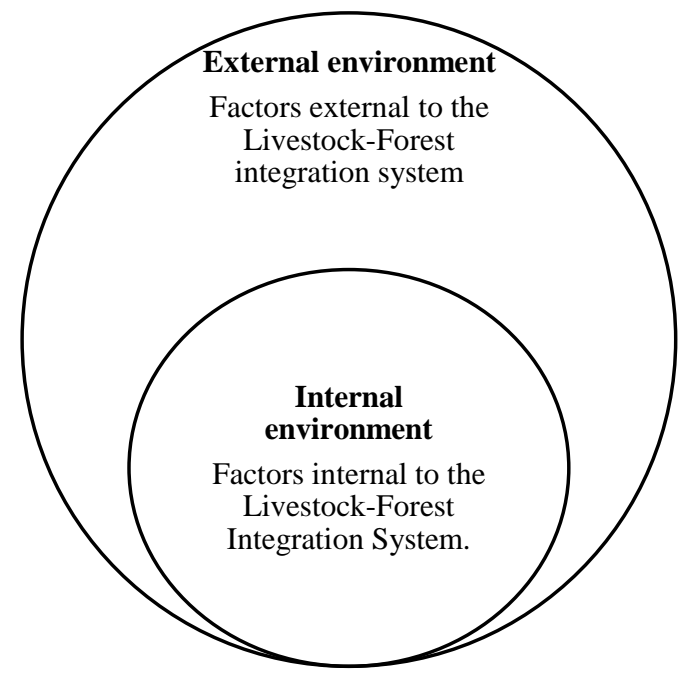

Figura 2. Caraterização e delimitação do ambiente interno e externo.

Figure 2. Characterization and delimitation of external and internal factors.

SOURCE: The authors (2018).

The qualitative approach used in the research consisted of semi-structured participatory interviews using a questionnaire developed according to Biassio and Silva (2015), to obtain information on the weaknesses, strengths, threats, and opportunities related to the systems of Livestock-Forest integration practices, to meet the guidelines of the SWOT analysis.

FLORESTA, Curitiba, PR, v. 50, n. 1, p. 1001 - 1010, jan/mar 2020.

Ansolin, R. D. et.al. 
For the internal environment, the items were listed and scored individually by each interviewee, while for the external environment the items were mapped through documentary and bibliographic review so that later the same key players evaluated the importance of the listed items.

The key players or interviewees were selected for their connection with the Livestock-Forest integration activity while some of them were suggested by Embrapa Agrossilvipastoril as well. A total of eleven interviewees, being 3 producers (livestock-forest integration), 3 farm managers (livestock-forest integration), 2 technical professionals from the forest and livestock production sector (forest engineer and veterinarian), and 3 collaborators from public and private institutions (Embrapa, Mato Grosso Institute of Agricultural Economics and ILPF Network), were interviewed during 2017. The research sought to cover the three areas (economic, environmental and social) of the sustainable development concept associated with the Forest Livestock Integration System, Nellore cattle and teak forest species.

To reduce the subjectivity of the conventional SWOT analysis, this study adopted a quantitative evaluation of the identified internal and external factors critical for business success. This procedure was done following the guidelines of Lee, Huang and Teng (2009), for building the internal and external factor matrices.

The Internal Factor (IFE) and External Factor (EFE) Evaluation Matrices were built based on the definition and consideration of key strengths and weaknesses and opportunities and threats, respectively, called critical success factors, obtained from the SWOT analysis. For building the matrices, the guidelines described by Biassio and Silva (2015) were considered, as follows:

1. Identification of internal (strengths and weaknesses) and external (opportunities and threats) factors.

2. Combined analysis of factors in relation to their importance by the key players. In this sense, each factor was assigned a weight ranging from 0.0 (not important) to 1.0 (very important). The greater the impact of the factor on the development of the livestock-forest integration system in Alta Floresta, the higher the weight assigned to it. The sum of the associated weights must be equal to 1.0.

3. Each factor was scored from 1 to 4 by the interviewees indicating their perception regarding the internal and external factors, for developing the livestock-forest integration system in Alta Floresta. The following scale was used: 1 = weakness/major threat; 2 = weakness $/$ minor threat; 3 = strength $/$ minor opportunity; 4 = strength / major opportunity.

4. Multiply the factor weight by its score to obtain a result for each factor.

5. Sum of all results to obtain the total points for the study area.

The internal and external factor matrices are interpreted following the guidelines presented in David (2006) and Biassio and Silva (2015). Total scores well below 2.5 indicate a weak internal organization, so for this study, if total scores are below 2.5, livestock-forest integration systems are not considered internally strong (more weaknesses/threats than strengths/opportunities) for development in the Alta Floresta region; the opposite is also true, that is, total scores above 2.5 indicate more strengths/opportunities than weaknesses/threats.

The present study was based on the Tectona grandis L. f. (teak) forest species because the studied region has edaphoclimatic parameters favorable for cultivating teak, which is also indicated for integration systems (DAMÁSIO et al., 2015; SILVA et al., 2014), especially for its moderate growth and high-quality wood with good added value. In addition, the species has been used in isolated commercial plantations in the region. Interest in teak cultivation has also been growing in the state of Mato Grosso, which is the main producer in Brazil and Latin America, according to a survey conducted by IBÁ (2017).

\section{RESULTS}

The information used in the SWOT matrix was obtained during the data survey. As suggested by David (2006), this information was classified into four groups: strengths and weaknesses (internal factors); opportunities and threats (external factors) as shown in Table 1.

Tabela 1. Respostas listadas nas entrevistas e consulta bibliográfica, seguida de suas respectivas pontuações, em ordem decrescente.

Table 1. Answers obtained in the field interviews and bibliographic search, followed by their respective scores, in descending order. 


\begin{tabular}{|c|c|c|}
\hline Factors & Strengths & Weaknesses \\
\hline \multirow{7}{*}{ Internal } & $\begin{array}{l}\text { Livestock areas available for integration in rural } \\
\text { properties; }\end{array}$ & $\begin{array}{l}\text { LFI systems lack technical and economic } \\
\text { indicators; }\end{array}$ \\
\hline & Production diversification; & High investment cost; \\
\hline & Technified production system; & System planning capability; \\
\hline & Pasture maintenance and restoration; & Long term system; \\
\hline & Fighting erosion and desertification; & New production system. \\
\hline & $\begin{array}{l}\text { System provides quality products and high productivity; } \\
\text { Alternative to deforestation. }\end{array}$ & \\
\hline & Opportunities & Threats \\
\hline \multirow{11}{*}{$\begin{array}{c}\text { Externa } \\
\quad l\end{array}$} & The region edaphoclimatic conditions are favorable; & Lack of technical assistance and rural extension; \\
\hline & Income diversification; & Lack of skilled labor; \\
\hline & High price paid for teakwood; & Bureaucracy for obtaining rural credit; \\
\hline & Regional development; & Needs of the consumer market; \\
\hline & State program supporting the CLFI systems; & $\begin{array}{l}\text { Lack of a logistic system (highways, railways, } \\
\text { and ports); }\end{array}$ \\
\hline & Attracting new companies; & $\begin{array}{l}\text { Wood price oscillation following the international } \\
\text { market (dollar); }\end{array}$ \\
\hline & High international demand for teak; & Regional focus on livestock; \\
\hline & Creating a logging industrial hub; & Few buyers for the national teak wood. \\
\hline & Credit policy (ABC Plan); & \\
\hline & Reducing production costs in the long term; & \\
\hline & Carbon credit market. & \\
\hline
\end{tabular}

The SWOT analysis considered all characteristics that may impact either negatively or positively the productive systems in the evaluated areas. To this end, the listed items were classified and the critical success factors impacting the livestock-forest integration system the most were extracted (Tables 2 and 3 ).

Tabela 2. Matriz AFI com ênfase em sistemas de integração pecuária-floresta, localizados no município de Alta Floresta, estado do Mato Grosso.

Table 2. IFE matrix focusing on forest-livestock integration systems in the Alta Floresta region, Mato Grosso.

\begin{tabular}{|c|c|c|c|}
\hline Strengths & Weight & Points & Result \\
\hline $\mathrm{S}_{1}$ : Livestock areas available for integration in rural properties & 0.13 & 4 & 0.52 \\
\hline $\mathrm{S}_{2}$ : Production diversification & 0.12 & 4 & 0.48 \\
\hline $\mathrm{S}_{3}$ : Technified production system & 0.10 & 4 & 0.4 \\
\hline $\mathrm{S}_{4}$ : Pasture maintenance and restoration & 0.07 & 3 & 0.21 \\
\hline $\mathrm{S}_{5}$ : Fighting erosion and desertification & 0.06 & 3 & 0.18 \\
\hline $\mathrm{S}_{6}$ : System provides quality products and high productivity & 0.07 & 3 & 0.21 \\
\hline $\mathrm{S}_{7}:$ Alternative to deforestation & 0.05 & 3 & 0.15 \\
\hline Weaknesses & Weight & Points & Result \\
\hline $\mathrm{W}_{1}$ : LFI systems lack technical and economic indicators & 0.11 & 2 & 0.22 \\
\hline $\mathrm{W}_{2}$ : High investment cost & 0.09 & 2 & 0.18 \\
\hline $\mathrm{W}_{3}$ : System planning capability & 0.08 & 2 & 0.16 \\
\hline $\mathrm{W}_{4}$ : Long term system & 0.06 & 1 & 0.06 \\
\hline $\mathrm{W}_{5}$ : New production system & 0.06 & 1 & 0.06 \\
\hline Total & 1 & & 2.83 \\
\hline
\end{tabular}

(S): Strengths; (W): Weaknesses. Source: The authors (2018).

The analysis results of the external factors allowed identifying the regional characteristics and particularities when considering integrating the forest component into extensive livestock areas, as shown in Table 3.

FLORESTA, Curitiba, PR, v. 50, n. 1, p. 1001 - 1010, jan/mar 2020

Ansolin, R. D. et.al.

ISSN eletrônico 1982-4688

DOI: $10.5380 /$ rf.v50 i1.60528 
Tabela 3. Matriz AFE com ênfase em sistemas de integração pecuária-floresta, localizados no município de Alta Floresta, estado do Mato Grosso.

Table 3. EFE matrix focusing on forest-livestock integration systems in the Alta Floresta region, Mato Grosso.

\begin{tabular}{|c|c|c|c|}
\hline Opportunities & Weight & Points & Result \\
\hline $\mathrm{O}_{1}$ : The region edaphoclimatic conditions are favorable & 0.1 & 4 & 0.4 \\
\hline $\mathrm{O}_{2}$ : Income diversification & 0.09 & 4 & 0.36 \\
\hline $\mathrm{O}_{3}$ : High price paid for teakwood & 0.08 & 4 & 0.32 \\
\hline $\mathrm{O}_{4}$ : Regional development & 0.07 & 4 & 0.28 \\
\hline $\mathrm{O}_{5}$ : State program supporting the CLFI systems & 0.06 & 4 & 0.24 \\
\hline $\mathrm{O}_{6}$ : Attracting new companies & 0.05 & 4 & 0.2 \\
\hline $\mathrm{O}_{7}$ : High international demand for teak & 0.03 & 3 & 0.09 \\
\hline $\mathrm{O}_{8}$ : Creating a logging industrial hub & 0.03 & 3 & 0.09 \\
\hline $\mathrm{O}_{9}:$ Credit policy (ABC Plan) & 0.01 & 3 & 0.03 \\
\hline $\mathrm{O}_{10}$ : Reducing production costs in the long term & 0.01 & 3 & 0.03 \\
\hline $\mathrm{O}_{11}$ : Carbon credit market & 0.01 & 3 & 0.03 \\
\hline Threats & Weight & Points & Result \\
\hline $\mathrm{T}_{1}$ : Lack of technical assistance and rural extension & 0.1 & 2 & 0.2 \\
\hline $\mathrm{T}_{2}$ : Lack of skilled labor & 0.09 & 2 & 0.18 \\
\hline $\mathrm{T}_{3}$ : Bureaucracy for obtaining rural credit & 0.09 & 2 & 0.18 \\
\hline $\mathrm{T}_{4}$ : Needs of the consumer market & 0.08 & 2 & 0.16 \\
\hline $\mathrm{T}_{5}$ : Lacking a logistic system (highways, railways, and ports) & 0.05 & 1 & 0.05 \\
\hline $\mathrm{T}_{6}$ : Wood price oscillation following the international market (dollar) & 0.05 & 1 & 0.05 \\
\hline $\mathrm{T}_{7}$ : Regional focus on livestock & 0.01 & 2 & 0.02 \\
\hline $\mathrm{T}_{8}$ : Few buyers for the national teak wood & 0.01 & 1 & 0.01 \\
\hline Total & 1 & & 3.24 \\
\hline
\end{tabular}

(O): Opportunities; (T): Threats. Source: The authors (2018).

\section{DISCUSSION}

The Internal Factor Evaluation Matrix (Table 2) shows the quantitative evaluation of the internal factors, strengths and weaknesses, identified in the SWOT analysis. The weighted total score for internal factors was 2.83, slightly higher than the 2.5 minimum average accepted in the method developed by David (2006) for the internal factor evaluation matrix. This result means that the livestock-forest integration system is internally strong in the study area and that the forestry component may be included in the extensive livestock areas, but careful monitoring is necessary so that the weaknesses do not outweigh strengths in the Alta Floresta region.

Additionally, Table 3 shows that the total score for external factors was 3.24, considerably higher than the 2.5 minimum accepted average indicated by the evaluation method for the external factor matrix. This result indicates that the studied region has a favorable external environment and the characteristics needed to develop the livestock-forest integration systems, i.e., better response to opportunities while being less sensitive to threats.

On the other hand, it is noteworthy that certain threats can make the system unfeasible, so that an appropriate short-, medium- and long-term planning is required to ensure efficient business introduction.

Given the above and based on the perceptions of the interviewees, it is important to support public and private initiatives in order to consolidate integration systems as a new agricultural and forestry alternative practice. The new practice is going to be adopted if feasibility conditions such as financial return and optimization of the workforce are present. To this end, it is necessary to ensure that technical assistance reaches the producer and to foster partnerships with organizations that support the agricultural sector.

Considering the results shown in each evaluation matrix, the most relevant critical factors, strengths and weaknesses (internal factors) and opportunities and threats (external factors) were carefully analyzed and the results are presented below.

\section{Internal Factors: Strengths of the Livestock-Forest Integration System}

Among the most relevant strengths, the $\left(S_{1}\right)$ livestock areas available for integration, $\left(S_{2}\right)$ possibility of production diversification, and $\left(\mathrm{S}_{3}\right)$ technified production system are highlighted.

$\left(\mathrm{S}_{1}\right)$ : Alta Floresta is located in the northern Mato Grosso region, where the livestock areas are concentrated, indicating available areas for integration. This information is corroborated by the Mato Grosso land 
cover and land use map (IBGE, 2016) which shows predominantly livestock activity in more than $40 \%$ of the state area.

Furthermore, Cordeiro et al. (2015) state that the process of integrating forest to pasture areas results in increased reforestation areas and improved environment and soil coverage by recycling the residues, thus improving the economic results.

$\left(\mathrm{S}_{2}\right)$ : The inclusion of the forestry component in the livestock area is strategically interesting since it diversifies and maximizes production per unit of area, allowing additional revenues in different periods over the planning horizon.

The income diversification provided by integration systems has been pointed out previously by Vilela et al. (2011) and Balbino et al. (2011). These authors mention that such integrated systems promote diversification of production, a more economically stable environment, increased income, and social gains since these rural properties generate more employment.

Similarly, integration systems require using more technology, so production becomes more efficient ensuring competitiveness against conventional production systems. Also, Cordeiro et al. (2015) mention that livestock-forest integration systems enable forest production without the burden of reducing the area for livestock, ensuring the same number of animals per unit of area.

$\left(\mathrm{S}_{3}\right)$ : From the viewpoint of the interviewees, similar to the conventional production systems, the livestock-forest integration system reaches high levels of technification. This result is possible because the system planning allows using machines and equipment to conduct activities making the integration system as competitive as conventional systems. The producer can adopt techniques combined between the system components, thus optimizing costs and revenues.

Also, Locatel (2012) reported that during the last five decades the Brazilian State has been contributing to the technification of rural territories, incorporating new areas to the production of agricultural and raw materials, increased production and productivity, generating more income in the agricultural sector.

\section{Internal Factors: Weaknesses of the Livestock-Forest Integration System}

Among the weaknesses, the most relevant items were: $\left(\mathrm{W}_{1}\right)$ lack of technical and economic indicators for livestock-forest integration systems, $\left(\mathrm{W}_{2}\right)$ high investment cost, and $\left(\mathrm{W}_{3}\right)$ system planning capacity. These items need to be carefully analyzed as they may endanger the business.

$\left(\mathrm{W}_{1}\right)$ : Cordeiro et al. (2015) state that production systems based on the integration model are aligned with one of the major current demands: food production with low environmental impact and rational land use. However, even though information on the real contribution of these systems and their technical and economic indicators is fundamental for the decision-making process, these data are scarce.

Given the above, it is necessary to invest in research to determine technical and economic data and indicators. Martha Junior et al. (2011) reported that these systems have been proposed as a technological solution for the sustainability criteria. However, economic conditions need to be evaluated to characterize and determine the potential economic benefits such as cost reduction due to the production of multiple products, and the effects of diversification on mitigating the risks associated with the business.

$\left(\mathrm{W}_{2}\right)$ : Because the integration systems propose to provide high productivity, they require technification of activities and high investments, especially in the stage of system implementation. This drawback makes it difficult for some producers to adopt the system due to the lack of capital and the fact that the return on investment ranges from 14 to 25 years for long-term planning projects.

Consequently, the landowner under-utilizes the areas, underscoring the importance of developing programs since much of the planted area is unfit for agricultural activities being, therefore, unproductive according to Ribeiro and Miranda (2009).

In this sense, Gontijo Neto et al. (2018) mention that even with public policies already implemented to encourage adopting more sustainable agricultural practices, especially the Low Carbon Agriculture Plan (Agricultura de Baixa Emissao de Carbono, ABC Plan), which includes credit lines for investment in integration system projects, new public policies that include tax benefits and the payment of environmental services to producers using more environmentally friendly technologies are also key to accelerating the adoption of integration systems by producers.

$\left(\mathrm{W}_{3}\right)$ : In view of the specificity of the integration system, planning is fundamental and the producer must be trained or supported during this stage. However, according to the interviewees, because this technological practice is still being introduced in rural properties, the producers lack planning capacity and technical support, as well.

FLORESTA, Curitiba, PR, v. 50, n. 1, p. 1001 - 1010, jan/mar 2020

Ansolin, R. D. et.al.

ISSN eletrônico 1982-4688

DOI: $10.5380 /$ rf.v50 i1.60528 
It is noteworthy that, at the time of decision making and planning, technical assistance usually stands out as a prominent factor for the success of the activity while the producer must also understand the property aptitude and the possible spaces to be explored.

Moreover, the producer must fulfill all the steps required for implementing the integration system, as recommended in the production systems to generate and reap all the benefits of such a system.

\section{External Factors: Opportunities for the Livestock-Forest Integration System}

Among the opportunities, the following items were the most relevant: $\left(\mathrm{O}_{1}\right)$ favorable edaphoclimatic conditions, $\left(\mathrm{O}_{2}\right)$ income diversification, and $\left(\mathrm{O}_{3}\right)$ high price paid for teakwood.

$\left(\mathrm{O}_{1}\right)$ : The favorable edaphoclimatic conditions in Alta Floresta provide high yield for both, livestock and forest. These characteristics are favorable from a technical and economic point of view, as they contribute to reducing/shortening the teak cutting cycle compared to the regions where teak originated and to other Brazilian regions, reaching similar productivities at very different ages, Mato Grosso (24 years) compared to India (34 years) and Nepal (37 years) approximately (SILVA et al., 2014; KOIRALA et al., 2017; UPADHYAY et al., 2005). Thus, allowing the economic return in a shorter time.

$\left(\mathrm{O}_{2}\right)$ : Most respondents rated the income diversification and stabilization promoted by the integration system in the rural property as relevant. The economic benefit brought by the forest with the sale of wood was highlighted for the livestock-forest integration system. While livestock generates a short-term annual income, the forest provides medium and long-term gains.

The integration system is considered a diversification alternative for a rural property, but to progress and settle in a given region, it must be competitive. For this purpose, all resources existing in each production system must be exploited with the utmost efficiency, in an appropriate and economically viable manner.

$\left(\mathrm{O}_{3}\right)$ : Teak forest species is widely planted in Myanmar, India, Vietnam, Indonesia, and Malaysia. However, the market is limited by supply due to species scarcity (FAO, 2011). On the other hand, the report issued by IBÁ (2017) stated that the area planted with teak and the teak market has been increasing in Brazil, but not significantly.

The current environment with a short supply of teak wood regulates the market for teak timber products at higher trading prices, favoring the producer during the negotiation process. The current situation implies greater added value to the product while guaranteeing specific markets, Asian countries such as China and India. However, this strategy is only feasible with the market guarantee.

Although the high price represents an opportunity in the past and current scenario, the possibility of a changing future economic scenario must be highlighted and considered as well, since forest production is a longterm activity. Given this, the decision-making from diversified systems to specialized production, as in the case of integration systems, must take into account market signals and ultimately, the price.

\section{External Factors: Threats to the Livestock-Forest Integration System}

Regarding the external factors, the main threats were: $\left(\mathrm{T}_{1}\right)$ lack of technical assistance and rural extension, $\left(\mathrm{T}_{2}\right)$ lack of skilled labor, and $\left(\mathrm{T}_{3}\right)$ bureaucracy for obtaining rural credit.

$\left(\mathrm{T}_{1}\right)$ : The distance and logistics are obstacles to the production chain and expansion of various businesses. Currently, the wood and food sectors in the country are concentrated in strategic regions, near major consumer centers and ports. However, the opposite is observed in Mato Grosso, agricultural production is widespread and far from the major consuming centers.

Given this, investments in infrastructure and logistics aimed at facilitating the production flow become crucial, a fact already felt and widely discussed by producers involved in the predominant activities in the region and their representations. The lack of such investments may make the creation of industrial centers unfeasible and, consequently, slow down regional development.

$\left(\mathrm{T}_{2}\right)$ : Also, because the evaluated farms are in a region with livestock mostly, the local workforce is specialized mainly in this field. When fostering the development of the forestry sector, it is essential that employees and the general population are able to seek training via public-private partnerships since professional qualification ensures final product quality and high efficiency throughout the production chain.

On the other hand, to integrate a new and differentiated activity such as the forestry component into the extensive cattle raising requires the industry and extension agencies to engage with the productive sector, divulging the forest productive potential to implement this new activity in the production chain of the region.

$\left(\mathrm{T}_{3}\right)$ : The implementation of integrated systems requires high and long-term investment, demanding credit availability, most often as credit lines directed to adopting the technologies and specific agricultural production systems. However, the surveyed farmers affirmed that they had difficulties to raise funds to implement 
the integration system via the ABC Plan credit line. Other producers said they never tried to access it because they had no knowledge of the program.

These statements corroborate Leite and Wesz Junior (2014), whose results show the difficulty in accessing rural credit. In this sense, it is important to outline strategic actions that promote simple and efficient access to these credit tools, encouraging the implementation of livestock-forest integration systems in the region.

\section{CONCLUSIONS}

The analysis allows concluding that:

- Integrating the forestry component with livestock, in addition to diversifying production, has the potential to increase revenue for the rural producer.

- Including the forestry component into extensive livestock areas is attractive from a market and local economic development standpoint, contributing to the strengthening of the forest-based sector.

- The analysis results suggest that Alta Floresta, in Mato Grosso, has the potential to implement livestockforest integration systems while the producers should be encouraged via private and public initiatives. However, public managers, institutions and the productive sector must have strategic planning in place to promote the integration of these activities.

\section{ACKNOWLEDGMENTS}

To Embrapa Agrosilvipastoril, the Mato Grosso Institute of Economics and Agriculture, the CLFI Network, Bacaeri Farm and Guavirá Industrial and Agroforestry for their valuable support and contributions to this research.

\section{REFERENCES}

BALBINO, L. C.; CORDEIRO, L. A. M.; SILVA, V. P.; MORAES, A.; MARTÍNEZ, G. B. Evolução tecnológica e arranjos produtivos de sistemas de integração lavoura pecuária floresta no Brasil. Pesquisa Agropecuária Brasileira, Brasília, v. 46, n. 10, p. i-xii, 2011.

BAMBOLIM, A.; DONDE, A. R. Análise temporal da Microbacia Mariana no município de Alta Floresta, Mato Grosso. Revista de Agricultura Neotropical, Cassilândia, v. 4, n. 3, p. 92-96, 2017.

BIASSIO, A; SILVA, I. C. Análise SWOT como ferramenta para avaliação da agrobiodiversidade em sistemas tradicionais de produção nos municípios de Antonina e Morretes/PR. Scientia Agraria, Curitiba, v. 16, n. 2, 2015.

CORDEIRO, L. A. M.; VILELA, L.; MARCHÃO, R. L.; KLUTHCOUSKI, J.; MARTHA JÚNIOR, G. B. Integração Lavoura-Pecuária e Integração Lavoura-Pecuária-Floresta: Estratégias para intensificação sustentável do uso do solo. Cadernos de Ciência \& Tecnologia, Brasília, v. 32, n. 1/2, p. 15-53, 2015.

DAMÁSIO, M.; SILVA, F. R. da; SANTOS, A. F. A.; RONDON NETO, R. M. Desbaste seletivo em um povoamento de Tectona grandis implantado em sistema de integração-lavoura-pecuária-floresta. Biodiversidade, Rondonópolis, v. 14, n. 3, p. 74-83, 2015.

DAVID, F. R. Strategic management: concepts and cases. 13 ed. Florence: Prentice Hall, 2006.

FAO - Food and Agriculture Organization of the United Nations The state of the world's land and water resources for food and agriculture (SOLAW) - Managing systems at risk. Rome and Earthscan, London: FAO. 2011. 137p.

GONTIJO NETO, M. M.; BORGHI, E.; RESENDE, Á. V.; ALVARENGA, R. C. Benefícios e desafios da integração lavoura-pecuária na melhoria da qualidade dos solos do Cerrado. International Plant Nutrition Institute, Piracicaba, v.1, n.161, 2018.

IBÁ - Indústria Brasileira de Árvores. Relatório IBÁ 2017. São Paulo: Pöyry/IBÁ, 2017. 80p.

IBGE - Instituto Brasileiro de Geografia e Estatística. Mapa da Cobertura e Uso da Terra do Mato Grosso. 2016. Disponível em: <https://www.ibge.gov.br/geociencias-novoportal/informacoes-ambientais/cobertura-euso-da-terra/10867-cobertura-e-uso-da-terra.html>. Acesso em: 01 de Jun. 2018.

IBGE - Instituto Brasileiro de Geografia e Estatística. Censo 2010.2010. <https://censo2010.ibge.gov.br/resultados.html>. Acesso em: 01 de Jun. 2018. 
KOIRALA, A.; KIZHA, A. R.; BARAL, S. Modeling Height-Diameter Relationship and Volume of Teak (Tectona grandis L. F.) in Central Lowlands of Nepal. Journal of Tropical Forestry and Environment, Nugegoda, v. 7, n. 1, p. 28-42, 2017.

LEE K. L.; HUANG, W. C.; TENG, J. Y. Locating the competitive relation of global logistics hub using quantitative SWOT analytical method. Quality \& Quantity, Bologna v. 43, n. 1, p. 87-107, 2009.

LEITE, S. P.; WESZ JUNIOR, V. J. Estado, políticas públicas e agronegócio no Brasil: Revisitando o papel do crédito rural. Revista Pós Ciências Sociais, São Luís, v. 11, n. 22, 2014.

LOCATEL, C. Tecnificação dos territórios rurais no Brasil: Políticas públicas e pobreza. Scripta Nova, Barcelona, v. XVI, n. 418, p. 1-8, 2012.

MARQUES, K. C. M.; SOUZA, R. P.; SILVA, M. Z. Análise SWOT da abordagem da contingência nos estudos da contabilidade gerencial. Revista Contemporânea de Contabilidade, Florianópolis, v. 12, n. 25, p. 117-136, 2015.

MARTHA JUNIOR, G. B.; ALVES, E. R. A.; CONTINI, E. Dimensão econômica de sistemas de integração lavoura-pecuária. Pesquisa Agropecuária Brasileira, Brasília, v. 46, n. 10, p. 1117-1126, 2011.

OLIVEIRA JÚNIOR, O. L.; CARNEVALli, R. A.; PERES, A. A. C.; REIS, J. C.; MORAES, M. C. M. M.; PEDREIRA, B. C. Análise econômico-financeira de sistemas integrados para a produção de novilhas leiteiras. Archivos de Zootecnia, Córdoba, v. 65, n. 250, p. 203-212, 2016.

PIRES, I. R. M.; LIMA, R. S.; DORICI, M.; SILVA, A. E. T.; PUGLIESI, E.; MOSCHINI, L. E.; CATOJO, A. M. Z. Proposta de manejo de águas pluviais e drenagem urbana do município de São Carlos - SP: aplicação da análise SWOT como método de avaliação de política pública. Revista Brasileira de Geografia Física, Recife, v. 9, n. 6, p. 2104-2120, 2016.

RIBEIRO, A.B.; MIRANDA, G.de M.; Estudo descritivo de programas de fomento em empresas florestais. Revista Ambiência, Guarapuava, v. 5 n. 1 p. 49-66, 2009.

SILVA, F. R.; SILVA, V. S. M.; MIRANDA, S. O. Crescimento de Tectona grandis em um uma plantação no município de Alta Floresta, Mato Grosso. Floresta, Curitiba, v. 44, n. 4, p. 577-588, 2014.

TURINI, T.; RIBEIRO, E. L. de A.; ALVES, S. J.; MIZUBUTI, I. Y.; SILVA, L. das D. F. da. Desempenho de bovinos inteiros e castrados em sistema intensivo de integração lavoura-pecuária. Semina: Ciências Agrárias, Londrina, v. 36, n. 3, p. 2339-2352, 2015.

UPADHYAY, A.; EID, T.; SANKHAYAN, P. L. Construction of site index equations for even aged stands of Tectona grandis (teak) from permanent plot data in India. Forest ecology and management, Amsterdam, v. 212, n. 1, p. 14-22, 2005.

VILELA, L.; MARTHA JUNIOR, G. B.; MACEDO, M. C. M.; MARCHÃO, R. L.; GUIMARÃES JÚNIOR, R.; PULROLNIK, K.; MACIEL, G. A. Sistemas de integração lavoura-pecuária na região do Cerrado. Pesq. agropec. bras., Brasília, v. 46, n. 10, p.1127-1138, 2011.

VIEIRA FILHO, J. E. R.; GASQUES, J. G. (Org.). Agricultura, transformação produtiva e sustentabilidade. Brasília: Ipea, 2016. 391 p. 